*akls View/Frint Document Cover Sheet tow

This document was retrieved from the Boeing ISEARCH System.

Accession \#: D196054854

Document \#: SD-WM-ER-461

Title/Desc:

TANK 241TY101 HEADSPACE GAS \& VAPOR CHARACTERIZATION REASULTS FOR SAMPLES COLLECTED IN 8/1994 \& 4/1995 


\begin{tabular}{|l|l|l|}
\hline ENGINEERING CHANGE NOTICE & i. ECN 626292 \\
\hline$\ldots y$
\end{tabular}

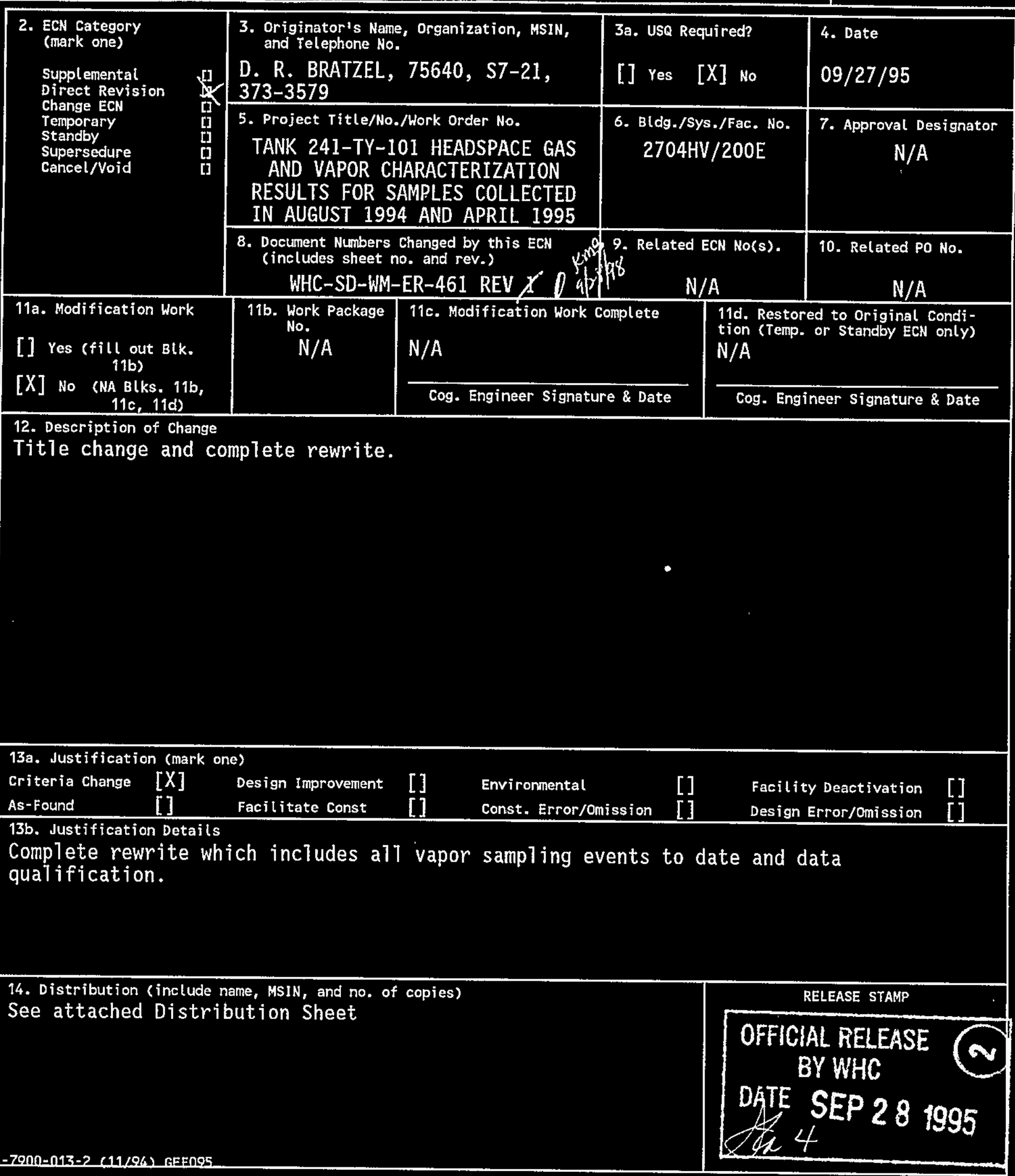




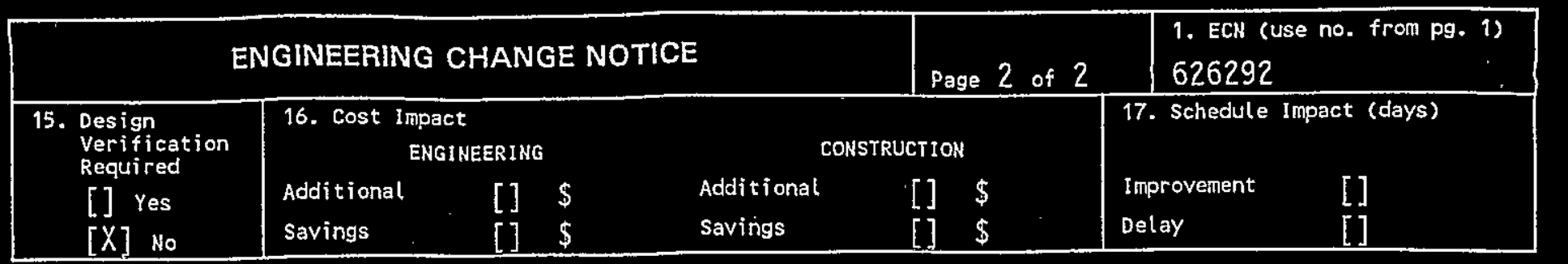

18. Change Impact Review: Indicate the related documents (other than the engineering documents ident ified on Side 1 ) that will be affected by the change described in Block 12 . Enter the affected document number in Block 19.

$\begin{array}{lr}\text { SDD/DD } & {[]} \\ \text { Functionat Design Criteria } & {[]} \\ \text { Operating Specification , } & {[]} \\ \text { Criticality Specification } & {[]} \\ \text { Conceptual Design Report } & {[]} \\ \text { Equipment Spec. } & {[]} \\ \text { Const. Spec. } & {[]} \\ \text { Procurement Spec. } & {[]} \\ \text { Vendor Information } & {[]} \\ \text { OM Manual } & {[]} \\ \text { FSAR/SAR } & {[]} \\ \text { Safety Equipment List } & {[]} \\ \text { Radiation Work Permit } & {[]} \\ \text { Environmental Impact Statement } & {[]} \\ \text { Environmental Report } & {[]} \\ \text { Environmental Permit } & {[]}\end{array}$

$\begin{array}{lll}{[]} & \text { Seismic/Stress Analysis } & {[]} \\ {[]} & \text { Stress/Design Report } & {[]} \\ {[]} & \text { Interface Control Drawing } & {[]} \\ {[]} & \text { Calibration Procedure } & {[]} \\ {[]} & \text { installation Procedure } & {[]} \\ {[]} & \text { Maintenance Procedure } & {[]} \\ {[]} & \text { Engineering Procedure } & {[]} \\ \text { [] } & \text { Operating Instruction } & {[]} \\ {[]} & \text { Operating Procedure } & {[]} \\ {[]} & \text { Operational Safety Requirement } & {[]} \\ {[]} & \text { IEFD Drawing } & {[]} \\ {[]} & \text { Cell Arrangement Drawing } & {[]} \\ {[]} & \text { Essential Material Specification } & {[]} \\ {[]} & \text { Fac. Proc. Samp. Schedule } & {[]} \\ {[]} & \text { Inspection Plan } & {[]} \\ \text { [] } & \text { inventory Adjustment Request } & {[]}\end{array}$

[] $\quad$ Tank Calibration Manual

[] Sparos Multiple Unit Listing

[] Test Procedures/Specification

[] Component Index

[] - ASME Coded item

[] Human Factor Consideration

[] Computer Software

[] Electric Circuit Schedule

[] ICRS Procedure

[] Process Control Manual/Plan

[] Process Flow Chart

[] Purchase Requisition

Tickler File

19. Other Affected Documents: (NOTE: Documents tisted below will not be revised by this ECN.) Signatures below indicate that the signing organization has been notified of other affected documents listed below. Document Number/Revision

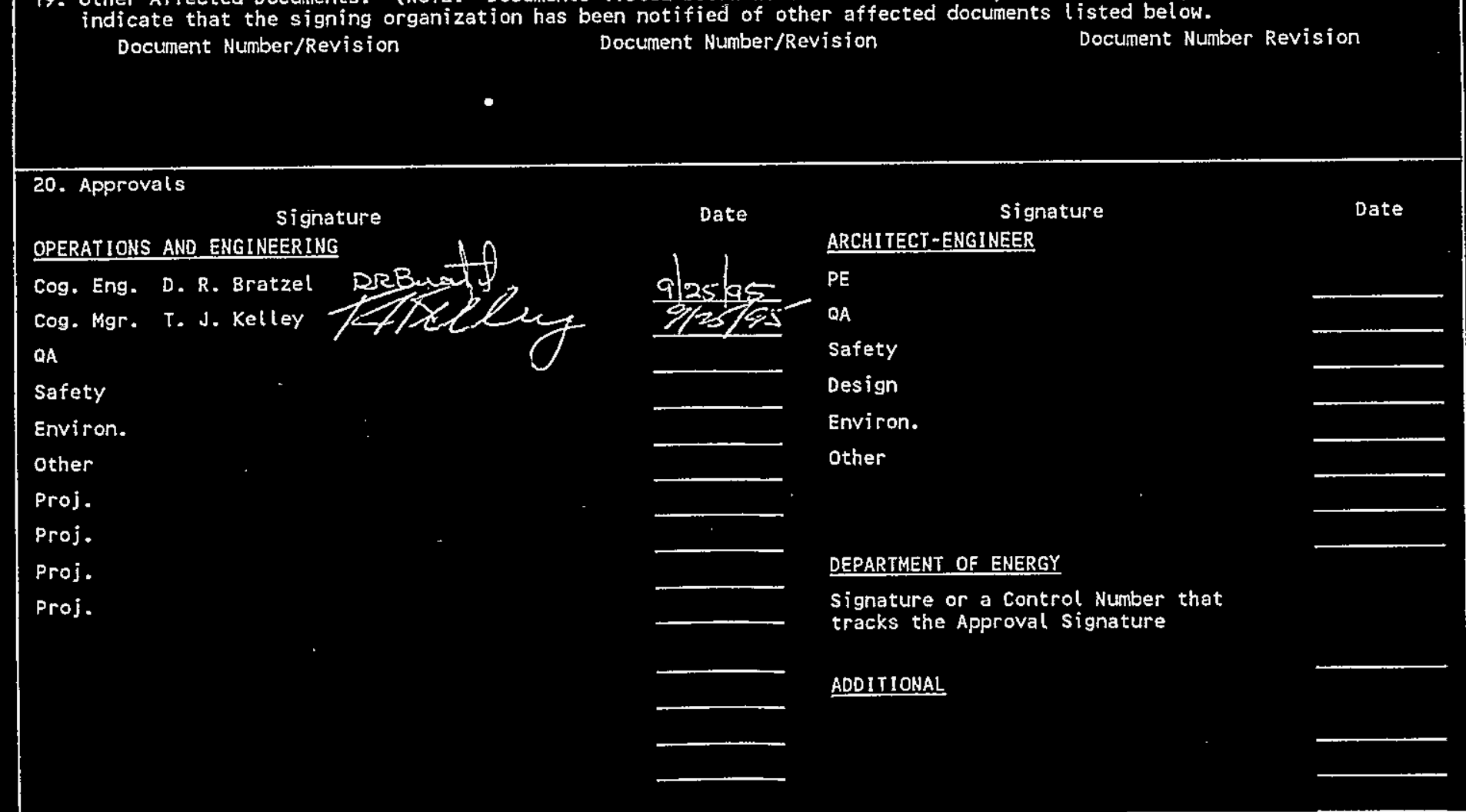




\section{RELEASE AUTHORIZATION}

Document Number: WHC-SD-WM-ER-461, REV 1

Tank 241-TY-101 Headspace Gas and Vapor

Document Title: Characterization Results for Samples Collected in

August 1994 and Apri 1995

Release Date: $\quad 9 / 28 / 95$

This document was reviewed following the procedures described in WHC-CM-3-4 and is:

\section{APPROVED FOR PUBLIC RELEASE}

WHC Information Release Administration Specialist:
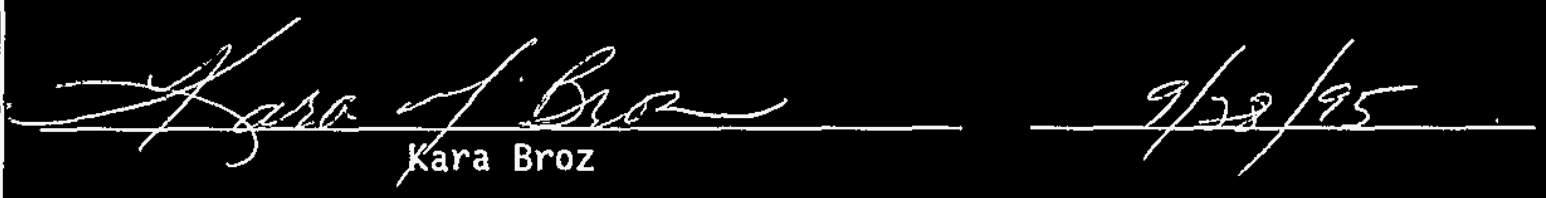

TRADEMARK DISCLAIHER. Reference herein to any specific commercial product, process, or service by trade name, trademark, manufacturer, or otherwise, does not necessarily constitute or imply its endorsement, recommendation, or favoring by the United States Government or any agency thereof or its contractors or subcontractors.

This report has been reproduced from the best available copy. Available in paper copy. Printed in the United States of America. To obtain copies of this report, contact:

Westinghouse Hanford Company - Document Contro] Services

P.0. Box 1970, Mailstop H6-08, Richland, WA 99352

Telephone: (509) 372-2420; Fax: (509) 376-4989 


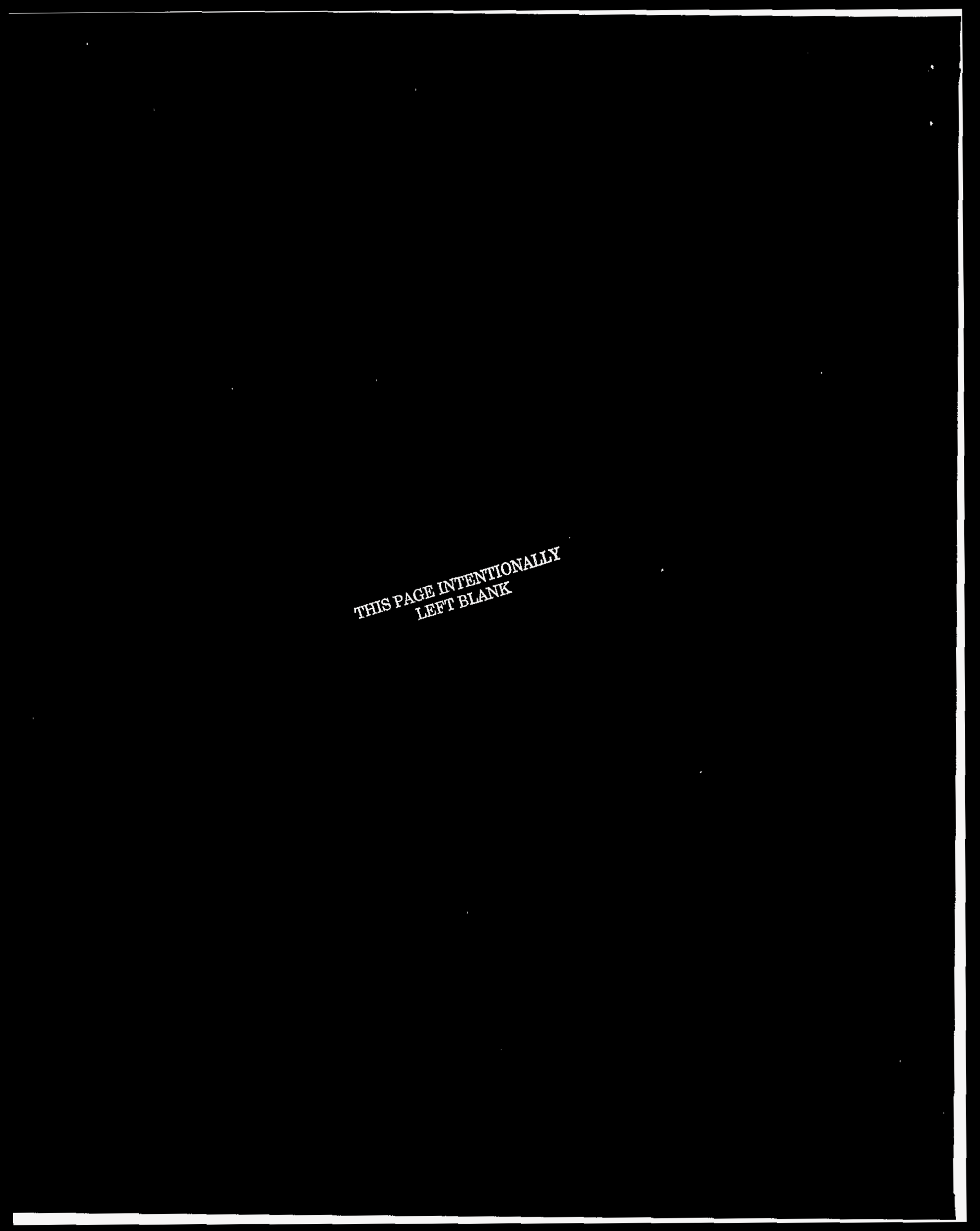


2. Title

TANK 241-TY-101 HEADSPACE GAS AND VAPOR

CHARACTERIZATION RESULTS FOR SAMPLES COLLECTED IN AUGUST 1994 AND APRIL 1995

5. Key Words

CHARACTERIZATION OBJECTIVES, TANK HEADSPACE, SAMPLING EVENT, INORGANIC GASES, ORGANIC VAPORS
3. Number

HHC-SD-WH-ER-461
4. Rev No.

1

6. Author

Name:

D. R. BRATZEL

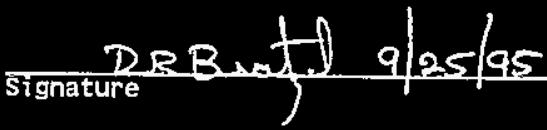

Organization/Charge code

$75640 / N 4 A B 1$

\section{Abstract}

Significant changes have been made to all of the original vapor characterization reports. This report documents specific headspace gas and vapor characterization results for all vapor sampling events to date. In addition, changes have been made to the original vapor reports to qualify the data based on quality assurance issues associated with the performing laboratories. 
THIS PAGE INTENTIONALII

LEETT BLANK 


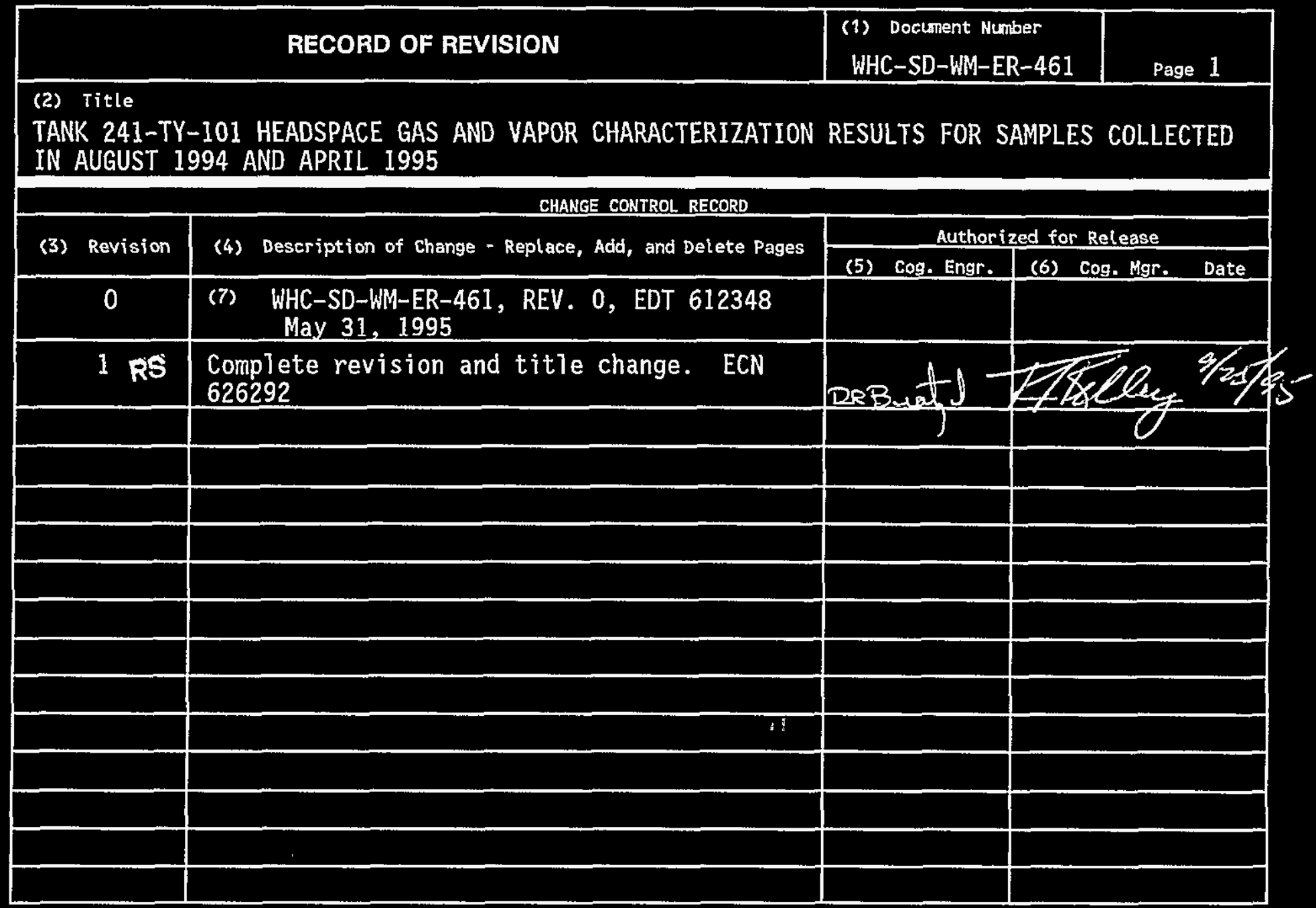


THIS PAGE INTENTIONALIY LEFT BLANK 


\title{
Tank 241-TY-101 Headspace Gas and Vapor Characterization Results for Samples Collected in August 1994 and April 1995
}

\author{
J. L. Huckaby
}

Pacific Northwest Laboratories

D. R. Bratzel

Westinghouse Hanford Company

Date Published

September 1995

Prepared for the U.S. Department of Energy

Office of Environmental Restoration and

Waste Management

\footnotetext{
(2)

Westinghouse

P.O Box 1970

Management and Operations Contractor for the

U.S. Department of Energy under Contrect DE.ACO6.87RL 10930
}

Approved for Public Release 


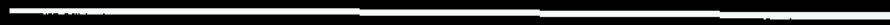




\section{Contents}

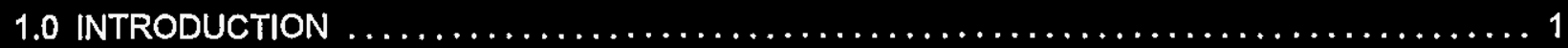

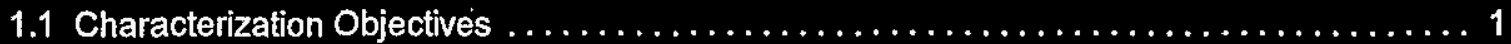

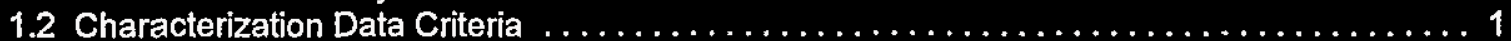

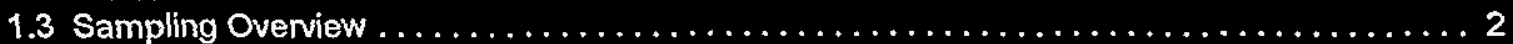

1.4 Tank Headspace Dynamics . . . . . . . . . . . . . . . . . . . . . . . .

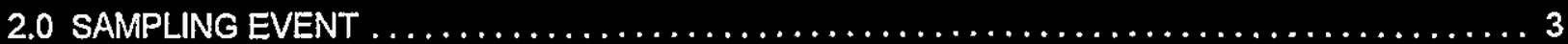

2.1 August 1994 In Situ Sampling Event . . . . . . . . . . . . . . . . . . . . . . . . . . . 3

2.2 April 1995 Vapor Sampling System Sampling Event . . . . . . . . . . . . . . . . . . 3

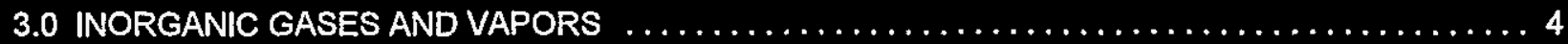

3.1 Ammonia, Hydrogen, and Nitrous Oxide . . . . . . . . . . . . . . . . . . . 4

3.2 Carbon Monoxide and Carbon Dioxide . . . . . . . . . . . . . . . . . . . . . . . 4

3.3 Nitric Oxide, Nitrogen Dioxide, Water and Tritium . . . . . . . . . . . . . . . . . . 5

3.4 Hydrogen Cyanide $\ldots \ldots \ldots \ldots \ldots \ldots \ldots \ldots \ldots \ldots \ldots \ldots \ldots \ldots \ldots \ldots \ldots \ldots \ldots \ldots \ldots$

3.5 Discussion of Inorganic Gases and Vapors $\ldots \ldots \ldots \ldots \ldots \ldots \ldots \ldots \ldots \ldots \ldots$

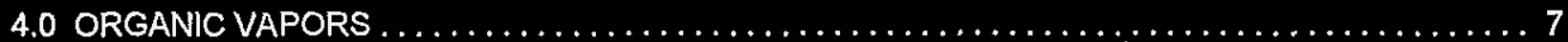

4.1 Positively ldentified Organic Compounds $\ldots \ldots \ldots \ldots \ldots \ldots \ldots \ldots \ldots \ldots \ldots \ldots \ldots$

4.2 Tentatively Identified Organic Compounds $\ldots \ldots \ldots \ldots \ldots \ldots \ldots \ldots \ldots \ldots \ldots \ldots$

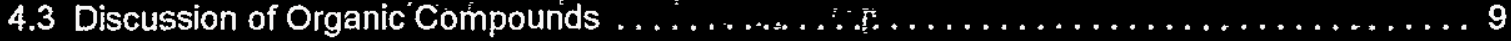

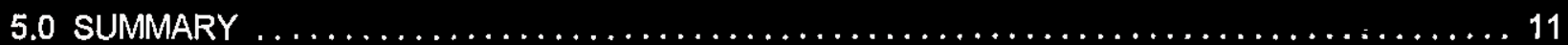

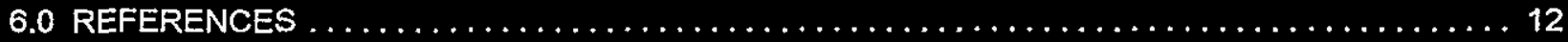

Acronyms and Abbreviations

$\begin{array}{ll}\text { CES } & \text { consensus exposure standard } \\ \text { EPA } & \text { Environmental Protection Agency } \\ \text { GC } & \text { gas chromatograph } \\ \text { GC/MS } & \text { gas chromatograph/mass spectrometer } \\ \text { ISS } & \text { in situ sampling } \\ \text { LFL } & \text { lower flammability limit } \\ \text { MS } & \text { mass spectrometer } \\ \text { NFPA } & \text { National Fire Protection Association } \\ \text { NPH } & \text { normal paraffinic hydrocarbon } \\ \text { ORNL } & \text { Oak Ridge National Laboratory } \\ \text { PNL } & \text { Pacific Northwest Laboratory } \\ \text { ppmv } & \text { parts per million by volume, } 1 \text { ppmv = 10-4 vol\% } \\ \text { TST } & \text { triple sorbent trap } \\ \text { Vol\% } & \text { percent by volume, } 1 \text { vol\% }=10,000 \mathrm{ppmv} \\ \text { VSS } & \text { Vapor Sampling System } \\ \text { WHC } & \text { Westinghouse Hanford Company }\end{array}$

\section{Acknowledgements}

The author wishes to thank Chris Simonen for her work verifying data and generating tables, and Shas Mattigod for his help with the construction and reviews of this document. 
THIS PAGE INTENTIONALLY LEET BLANK 
WHC-SD-WM-ER-461 REV. 1

Tank 241-TY-101 Headspace Gas and Vapor Characterization Results

for Samples Collected in August 1994 and April 1995

\subsection{INTRODUCTION}

\subsection{Characterization Objectives}

Tank TY-101 headspace gas and vapor samples were collected and analyzed to help determine the potential risks of fugitive emissions to tank farm workers. The drivers and objectives of waste tank headspace sampling and analysis are discussed in Program Plan for the Resolution of Tank Vapor /ssues (Osborne and Huckaby 1994). This report primarily discusses results from the April 1995 sampling event, but also includes selected results of the August 1994 sampling event. The tank TY-101 headspace was sampled in August 1994 in accordance with Safety Assessment for Gas Sampling All Ferrocyanide Tanks (Farley 1991), and in April 1995 in accordance with Data Quality Objectives for Generic $/ n$-Tank Health and Safety Issue Resolution (Osborne et al. 1994).

\subsection{Characterization Data Criteria}

Data Quality Objectives for Generic In-Tank Health and Safety Issue Resolution describes parameters for data collection to ensure appropriate conclusions can be drawn from the data. Tank headspace characterization data was collected to help in the evaluation of 1) headspace flammability, and 2) identification and quantification of compounds of toxicological concern.

Single Shell Tank Interim Operational Safety Requirements (Dougherty 1995) specifies that combustible constituents in tank headspaces be maintained below $25 \%$ of the lower flammability limit (LFL). This essentially agrees with National Fire Protection Association requirements that combustible concentrations be maintained at or below $25 \%$ of the LFL (NFPA 1992). However, current governing operating specifications for Watchlist tanks, such as tank TY-104, specify that combustible constituents be maintained at or below $20 \%$ of the LFL (WHC 1995a).

Headspace characterization data are used by Westinghouse Hanford Company (WHC) Tank Waste Remediation Systems Industrial Hygiene as source term data in the industrial hygiene strategy to protect workers from tank fugitive emissions. Because selection of worker protective equipment must be based on industrial hygiene monitoring of the work place and not on source term data (29 CFR 1910.120), tank headspace characterization data can not be used for this purpose. Furthermore, because there are mechanisms by which headspace constituents can be either diluted or concentrated as they are released to the atmosphere, the headspace characterization data should not be considered to be representative of emissions at the point of emission.

These statements notwithstanding, the data quality objectives document specifies that the industrial hygiene group be advised if constituents with toxicological properties exceed $50 \%$ of the appropriate consensus exposure standard (CES) for non-carcinogens, or $10 \%$ of the appropriate CES for carcinogens. A CES is defined as the most stringent of known regulatory or recommended toxicological values for the workplace (Osborne et al. 1994). 


\subsection{Sampling Overview}

Tank TY-101 was vapor sampled in August 1994 using the in situ sampling (ISS) method, and again in April 1995 using the more robust vapor sampling system (VSS) method. Because the ISS sample volume flow measurement used during the August 1994 event was inherently less accurate than that of the VSS, the sorbent trap samples from the ISS event are not considered to be equivalent to those from the VSS sampling event (Huckaby and Babad 1995). Furthermore, there are other discrepancies between results from the ISS and VSS methods that are not understood (Huckaby 1994a), and until the ISS method has been validated and the discrepancies resolved, results from early ISS events should be considered suspect.

Nevertheless, a brief description of the ISS event and hydrogen cyanide sampling results from the August 1994 ISS event are presented below, because this analyte was not sampled for during the VSS event. Huckaby and Babad (1995) describe the bases for using the ISS method for hydrogen cyanide, and why it was not sampled for during the VSS event. All other results presented here are from the April 1995 VSS sampling event.

Samples collected are thought to have been representative of the tank TY-101 headspace when the tank was sampled, and sample analyses were designed to provide a reasonably accurate and complete characterization of the significant headspace constituents (Meacham et al. 1995). No assessment has been made of how the tank TY-101 headspace composition changes with time, though studies of tank C103 suggest that composition changes probably occur very slowly in the passively ventilated tanks (Huckaby and Story 1994).

\subsection{Tank Headspace Dynamics}

Tank TY-101 is the first tank in a 3-tank cascade with tanks TY-102 and TY-103. It is connected to tank TY102 via a 7.4-cm (2.9-in.) inside diameter, 7.6-m (25-ft) long cascade line. Tanks TY-102 and TY-103 are connected by a similar cascade line. Because these cascade lines connect the headspaces of these tanks, gases and vapors originating from the wastes in tank TY-102 or tank TY-103 may be transferred to tank TY101 (unless the cascade lines are obstructed). At this time, however, no headspace characterization data are available for tank TY-102 to assess the potential effect on tank TY-101.

The cascade of tanks TY-101, TY-102, and TY-103 is passively ventilated, which means that the tanks are allowed to exhale air, waste gases, and vapors as the barometric pressure falis, and inhale ambient air as the barometric pressure rises. Each of these tanks has its own filtered breather riser. Barometric pressure typically rises and falls on a diurnal cycle, producing an average daily exchange of air equal to about $0.46 \%$ of each tank headspace (Huckaby 1994b). Changes in the concentrations of tank headspace constituents due to barometric pressure changes are consequently very slow. 


\subsection{SAMPLING EVENT}

\subsection{August 1994 In Situ Sampling Event}

Tank TY-101 was sampled using ISS methods on August 4, 1994 by WHC Sampling and Mobile Laboratories. This sampling was conducted to satisfy requirements of Safety Assessment for Gas Sampling All Ferrocyanide Tanks (Farley 1991). Samples for hydrogen cyanide were collected from a point approximately $7.6 \mathrm{~m}$ below the top of the flange on riser 3, between 2:00 p.m. and 3:30 p.m.

Huckaby and Babad (1995) give a general description of the ISS method and equipment. Pingel (1994) provides field sampling information for the tank TY-101 August 1994 ISS event, and Mahon (1995) provides revised sample volume measurements. In addition to the hydrogen cyanide results presented below, Pool et al. (1995) provide sample preparation and analysis results for selected organic and inorganic vapors.

\subsection{April 1995 Vapor Sampling System Sämpling Event}

Headspace gas and vapor samples were collected from tank TY-101 using the VSS on April 6, 1995 by WHC Sampling and Mobile Laboratories (WHC 1995b). Sample collection and analysis were performed as directed by Tank 241-TY-101 Tank Characterization Plan (Homi 1995). The tank headspace temperature was determined to be $15.6^{\circ} \mathrm{C}$. Air from the tank TY-101 headspace was withdrawn from a single elevation via a 5.5-m long heated sampling probe mounted in riser 3 , and transferred via heated tubing to the VSS sampling manifold. All heated zones of the VSS were maintained at approximately $40^{\circ} \mathrm{C}$. All tank air samples were collected between 10:14 a.m. and 1:59 p.m., with no anomalies noted.

Sampling media were prepared and analyzed by WHC, Oak Ridge National Laboratories (ORNL), and Pacific Northwest Laboratories (PNL). The 40 tank air samples and 2 ambient air control samples collected are listed in Table 2-1 by analytical laboratory. Table 2-1 also lists the 14 trip blanks and 14 field blanks provided by the laboratories.

A general description of vapor sampling and sample analysis methods is given by Huckaby and Babad (1995). The sampling equipment, sample collection sequence, sorbent trap sample air flow rates and flow times, chain of custody information, and a discussion of the sampling event itself are given in WHC (1995b). 
WHC-SD-WM-ER-461 REV. 1

\subsection{INORGANIC GASES AND VAPORS}

Analytical results of sorbent trap and SUMMA ${ }^{T M, 4}$ canister tank air samples for selected inorganic gases and vapors are given in Table 3-1 in parts per million by volume (ppmv) in dry air. The concentration of water vapor given in Table 3-1 has been adjusted to tank conditions given in Section 3.3. Inorganic analyte sorbent traps and SUMMA ${ }^{\text {TM }}$ canisters were prepared and analyzed by PNL (Pool et al. 1995, Klinger et al. 1995).

Analyses of the VSS event sorbent traps were performed within 13 days of sample collection, analyses of VSS event SUMMA ${ }^{T M}$ canisters for inorganic compounds were performed 12 days after sample collection, and analyses of the ISS event hydrogen cyanide sorbent traps were performed within $\mathbf{3 5}$ days of sample collection (Ligotke 1995). This satisfied the 60-day holding time requirement of the WHC quality assurance project plan (Keller 1994). Though no holding time study has been performed to address the stability of compounds in SUMMA ${ }^{T M}$ canisters in the chemical matrix of the tank samples, these inorganic compounds (i.e., the permanent gases) would be expected to be very stable in the SUMMA ${ }^{T M}$ canisters, and the results may not have been affected even if the 60 day holding time requirements had been exceeded. Sample preparation and analysis were performed at PNL quality assurance impact level 2, except for the hydrogen cyanide results, which were produced at PNL quality assurance impact level 3.

\subsection{Ammonia, Hydrogen, and Nitrous Oxide}

The concentration of ammonia in the headspace of TY-101 was measured to be $16 \mathrm{ppmv}$. Ammonia has been observed in virtually all of the passively ventilated waste tanks that have been sampled, at concentrations ranging from about 3 ppmv in tank C-108 (Lucke et al. 1995), to $1040 \mathrm{ppmv}$ in BY-108 (McVeety et al. 1995). Given the LFL of ammonia in air is about $15 \%$ by volume (vol\%), the measured 16 ppmv corresponds to about $0.01 \%$ of the LFL, and does not contribute appreciably to the flammability of the headspace.

The concentration of hydrogen in tank TY-101 was determined to be $<93$ ppmv in each of the 3 SUMMA canister samples. Hydrogen in the waste tanks is of concern as a fuel. Given that the LFL for hydrogen in air is about 4 vol\%, a 93 ppmv hydrogen concentration in tank TY-101 would correspond to about $0.23 \%$ of its LFL. At this concentration, hydrogen is not a flammability concern in tank TY-101.

The reported nitrous oxide concentration in tank TY-101, $98 \mathrm{ppmv}$, is typical of other passively ventilated tanks that have been sampled. Under the proper conditions, nitrous oxide can serve as an oxidizer to support combustion. However, Cashdollar et al. (1992) found that nitrous oxide had no significant effect on the flammability of hydrogen and air mixtures for hydrogen concentrations less than 20 vol\%, and that "small amounts of nitrous oxide (relative to air) do not appear to have much effect on the flammability". Their results suggest the measured nitrous oxide concentration is much too low to have a significant effect on the flammability of the tank TY-101 headspace.

\subsection{Carbon Monoxide and Carbon Dioxide}

Carbon monoxide in the tank TY-101 headspace was measured to be $<12 \mathrm{ppmv}$ in each of the 3 SUMMA $^{\text {TM }}$ canister samples. In ambient air it typically ranges from 0.05 to 0.15 ppmv. Because different analytical methods have been used to measure carban monoxide in the waste tanks, the information on carbon monoxide has varied from tank to tank. However, elevated waste tank headspace carbon monoxide

'SUMMA is a trademark of Molectrics, Inc., Cleveland, Ohio. 
concentrations are common, and are thought to be due to the decomposition of organic waste in the tanks. Carbon monoxide has not been measured at very high levels in any of the waste tanks, and the highest level measured to date was [26.7 ppmv] in tank C-103 (Huckaby and Story 1994).

The carbon dioxide concentration in the tank TY-101 headspace, measured in the 3 SUMMA ${ }^{\text {TM }}$ canister samples to be 83 ppmv, is significantly lower than it is in ambient air. Carbon dioxide introduced by air exchange with the atmosphere is readily absorbed by caustic supernatant and interstitial liquids of the waste tanks, and converted to carbonate in solution. Carbon dioxide is normally present in the ambient air at a concentration of 350 to 400 ppmv, and is typically lower than ambient in the waste tank headspaces. The 2 ambient air samples collected at the start of the tank TY-101 April 1995 sampling event, for example, were measured to have an average 374 ppmv of carbon dioxide.

\subsection{Nitric Oxide, Nitrogen Dioxide, Water and Tritium}

Nitric oxide and nitrogen dioxide concentrations in the tank TY-101 headspace were determined to be 0.11 ppmv and s 0.04 ppmv, respectively. These are acid gases that would have very low equilibrium concentrations above the high pH sludge in tank TY-101. The measurable presence of nitric oxide is not uncommon in the waste tank headspaces, and may be due to its formation from oxygen and nitrogen in the radiation field of the headspace. These constituents could potentially serve as oxidizers to support combustion, but at the measured concentrations would have a negligible effect on the fiammability of the tank TY-101 headspace.

The water vapor concentration of tank TY-101 was determined to be about $10.3 \mathrm{mg} / \mathrm{L}$, at the measured tank headspace temperature of $15.6^{\circ} \mathrm{C}$ and pressure of $982.8 \mathrm{mbar}(737.3 \mathrm{torr})$, (WHC 1995b). This corresponds to a water vapor partial pressure of $13.7 \mathrm{mbar}\left(10.3\right.$ torr), to a dew point of $11.7^{\circ} \mathrm{C}$, and to a relative humidity of $77 \%$.

Silica gel sorbent traps were used to test for tritium. It is assumed that tritium produced by the waste combines with hydroxide ions to form tritium-substituted water. Evaporation of the tritium-substituted water would then result in airborne radioactive contamination. Silica gel sorbent traps adsorb virtually all (normal and tritium-substituted) water vapor from the sampled tank air, and are analyzed at the WHC 222-S laboratory. Radiochemical analysis of the silica gel trap indicated the total activity of the headspace to be less than $50 \mathrm{pCi} / \mathrm{L}$ (WHC 1995b).

\subsection{Hydrogen Cyanide}

Analysis of the hydrogen cyanide specific sorbent traps indicated the concentration of this analyte to be below 0.01 ppmv in all 3 samples. The absence of hydrogen cyanide at measurable concentrations is consistent with the expectation that an acid gas, such as hydrogen cyanide, would not exist at significant concentrations above the caustic waste in tank TY-101. No hydrogen cyanide has been detected in any of the 10 waste tank headspaces sampled for this analyte.

2 The carbon monoxide measurement in tank C-103 was made by Oregon Graduate Institute of Science and Technology, and placed in brackets to emphasize it should be considered secondary data. 


\section{WHC-SD-WM-ER-461 REV. 1}

\subsection{Discussion of Inorganic Gases and Vapors}

Aside from water vapor and carbon dioxide, the most abundant waste constituents in the tank TY-101 headspace are nitrous oxide and ammonia. These compounds, along with hydrogen, have usually been the most abundant waste species. The concentration of nitrous oxide in tank TY-101 is typical of the passively ventilated tanks that have been sampled, but the ammonia concentration in TY-101 is relatively low.

The relative standard deviations of the inorganic gas and vapor results given in the last column of Table 3-1 are good for the methods used. Relative standard deviations range from $1.3 \%$ for water vapor to about 18 $\%$ for nitric oxide results. The relatively poor precision of the nitric oxide results is due to the variability of background contamination present in these sorbent traps. Because the precision reported depends both on sampling parameters (e.g., sample flow rate and flow time for sorbent traps) and analytical parameters (e.g., sample preparation, dilutions, etc.), small relative standard deviations suggest proper control was maintained both in the field and in the laboratories. 


\subsection{ORGANIC VAPORS}

Organic vapors in the tank TY-101 headspace were sampled using SUMMA ${ }^{\mathrm{TM}}$ canisters, which were analyzed by PNL, and triple sorbent traps (TSTs), which were analyzed by ORNL. Both PNL and ORNL used a gas chromatograph (GC) equipped with a mass spectrometer (MS) detector to separate, identify, and quantitate the analytes. Descriptions of sample device cleaning, sample preparations, and analyses are given by Jenkins et al. (1995a) and Klinger et al. (1995).

SUMMA ${ }^{\text {TM }}$ sample results should be considered to be the primary organic vapor data for tank TY-101. PNL results were produced at PNL quality assurance impact level 2. All PNL SUMMA ${ }^{T M}$ canister analyses were performed within 13 days after sample collection (Ligotke 1995), well within the specified 60-day holding time (Keller 1994).

ORNL analyses of TST samples from this and other waste tanks generally agree with, support, and augment the SUMMA ${ }^{T M}$ sample results. However, because certain WHC quality assurance requirements were not satisfied by ORNL, the quality assurance assiessment of ORNL by Hendrickson (1995) should be reviewed before results unique to the TST samples are used for decision making.

All TSTs prepared by ORNL had 3 surrogate compounds added to evaluate sample matrix effects, potential handling, storage, and shipment problems, and analytical instrumentation performance (Jenkins et al. 1995a). ORNL evaluated the surrogate recoveries using a statistical approach similar to that prescribed by SW 846 Method 8260 A Volatile Organic Compounds by Gas Chromatography/Mass Spectrometry (GCMS) Capillary Column Technique (EPA 1992). Using this approach, ORNL reported that all surrogates had standard deviation values within the $95 \%$ confidence interval for variance, indicating that no bias was introduced in the measurement of analyte quantities (Jenkins 1995a).

\subsection{Positively Identified Organic Compounds}

Positive identification of organic analytes using the methods employed by PNL and ORNL involves matching the GC retention times and MS data from a sample with that obtained by analysis of standards. The concentration of an analyte in the sample is said to be quantitatively measured if the response of the GC/MS has been established at several known concentrations of that analyte (i.e., the GC/MS has been calibrated for that analyte), and the MS response to the analyte in the sample is between the lowest and highest responses to the known concentrations (i.e., the analyte is within the calibration range).

ORNL and PNL were assigned different lists of organic compounds, or target analytes, to positively identify and measure quantitatively. The ORNL target analyte list was derived from a review of the tank C-103 headspace constituents by a panel of toxicology experts (Mahlum et al. 1994). The PNL target analyte list included 39 compounds in the Environmental Protection Agency (EPA) task order 14 (TO-14) method, which are primarily halocarbons and common industrial solvents (EPA 1988), plus 14 analytes selected mainly from the toxicology panel's review of vapor data on tank C-103.

Table 4- 1 lists the organic compounds positively identified and quantitated in SUMMA ${ }^{\text {TM }}$ samples. All compounds in Table 4-1were analyzed according to the TO-14 methodology, except for the methane, which was analyzed with the inorganic gases (Klinger et al. 1995). Only 2 of the 39 TO-14 target analytes (trichlorofluoromethane and tetrachloromethane) and only 4 of the 14 additional target analytes were measured to be above the $0.005 \mathrm{ppmv}$ detection limit of the analyses. Averages reported are from analyses of 3 SUMMA ${ }^{\text {TM }}$ canister samples.

Jenkins et al. (1995a) report the positive identification of 23 of the 27 target analytes in TST samples. Dichloromethane, $\mathrm{n}$-heptane, dibutyl butylphosphonate, and tributyl phosphate were the only TST target 


\section{WHC-SD-WM-ER-461 REV. 1}

analytes not detected. The average concentrations of the detected target analytes, from the analysis of 4 TSTs, are given in Tables 4-2, 4-3, and 4-4. Table 4-2 lists the positively identified, quantitated anaiytes, Table 4-3 lists the positively identified analytes which were not quantitated (because the measurement was outside the calibration range for at least 1 sample), and Table 4-3 lists the positively identified analytes which exceeded their practical holding times. Tables 4-2, 4-3, and 4-4 are mutually exclusive, so that no analyte appears in more than 1 of these tabies. Despite calibration of the instrument over about a 20-fold concentration range, 17 of the 23 compounds positively identified in TST samples were not quantitated.

The ORNL practical holding time is defined as the holding time for which there is a $15 \%$ risk that the concentration of an analyte in the sample will be below its initial concentration. As indicated in Table 4-4, butanal and 1-butanol exceeded their practical holding times, and may have been affectad by the 25 day period between sample collection and analysis (Jenkins 1995b). Jenkins et al. (1995b) describe the ORNL practical holding time study, and report the practical holding times of butanal, and 1-butanol are 1 and 17 days, respectively. It is worth noting that the contractual holding time for the TST samples was 60 days.

Both PNL and ORNL report target analyte concentrations in ppmv of analyte in dry air. To correct for the measured water vapor content of tank TY-101 and obtain concentration in ppmv of analyte in moist tank air, multiply the dry-air ppmv concentrations by 0.986 .

Eleven target analytes were common to both TST and SUMMA ${ }^{\mathrm{TM}}$ analyses. Table 4-5 lists these, and their reported average concentrations in TST and SUMMA ${ }^{\mathrm{TM}}$ samples. Results from these 2 sampling and analytical methods agree fairly well. As indicated in Table 4-5, the reported concentrations of propanone,

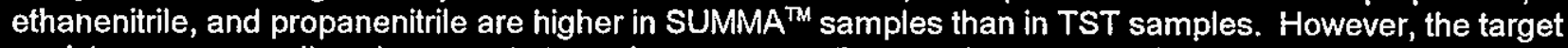
analytes are generally only present at very low concentrations, and none are at levels of concern.

The only analyte in Tables 4-1 through 4-4 above $0.1 \mathrm{ppmv}$ is propanone, measured to be an average 0.14 ppmv in SUMMA ${ }^{\mathrm{TM}}$ samples. At the reported concentrations, the target analytes do not individually or collectively represent a flammability hazard.

\subsection{Tentatively Identified Organic Compounds}

In addition to the target analytes, the ORNL and PNL analytical procedures allow the tentative identification of other organic compounds. Tentative identification of analytes was performed by comparing the MS molecular fragmentation patterns with a library of known MS fragmentation patterns. This method allows an organic analyte to be identified (with reasonable certainty) as an alkane, a ketone, an aidehyde, etc., and may also determine its molecular weight. The method usually does not, however, allow the unambiguous identification of structural isomers, and this ambiguity increases with analyte molecular weight. Using this method, many analytes can be tentatively identified with reasonable confidence without having to inject standards of each into the GCMS to determine their GC retention times or specific MS patterns.

By the nature of the sampling devices, virtually all organic vapors present in the tank headspace are collected by both TST and SUMMA ${ }^{\text {TM }}$ samples. Analyses of the samples are designed to recover, separate, and identify the organic vapors in the samples. TSTs are not good for collecting highly volatile compounds (i.e., molecules more volatile than propane), but are quite good for most others. In contrast, the recovery of very low volatility compounds (e.g., molecules with more than about 15 carbon atoms) and some polar compounds with moderate volatility (e.g., butanal) from SUMMA ${ }^{T M}$ samples has been problematic.

The sole tentatively identified compound reported in SUMMATM samples, methanol, with its estimated concentration, is given in Table 4-6. The list of tentatively identified compounds detected in TST samples, and their estimated concentrations, is given in Table 4-7. Compounds are listed in Table 4-7 according to 
the order by which they eluted chromatographically. The averages reported by ORNL in Table 4-7 are all 4-sample averages, and if an analyte was not detected in a sample, its concentration in that sample was considered to be zero for averaging purposes. Estimated concentrations are in $\mathrm{mg} / \mathrm{m}^{3}$, based on dry air at $0^{\circ} \mathrm{C}$ and 1.01 bar.

Because the list of tentatively identified organic compounds in TST samples is rather long and locating any given compound may be difficult, the list has been sorted both alphanumerically by compound name (Table 4-8), and also in order of decreasing estimated concentrations (Table 4-9). Numbers in the first columns of Tables 4-8 and 4-9 (Cmpd \#) identify the location of the compound in Table 4-7.

The ORNL and PNL methods used to tentatively identify and estimate concentrations are described by Jenkins et al. (1995a) and Klinger et al. (1995), respectively, and should be reviewed before this data is used for decision making. Concentrations given in Tables 4-6 and 4-7 should be considered rough estimates.

\subsection{Discussion of Organic Compounds}

The organic compounds listed in Tables 4-1 through 4-9 may be classified as either 1) organic compounds added to tank TY 101 as waste that are still evaporating, or 2) organic compounds that have been generated by reactions of the original waste.

Organic vapors in the first category, those that were placed into the tank as waste, include the semivolatile straight-chain alkanes, which were used as diluents of tributyl phosphate in various plutonium extraction processes. These alkanes (i.e., $n$-undecane, $n$-dodecane, n-tridecane, n-tetradecane, and n-pentadecane) are often referred to in Hanford site literature as the normal parafinic hydrocarbons (NPHis). Though NPHs are positively identified in tank TY-101, their concentrations are very low compared to other NPH-rich tanks in the 241-BY and 241-C farms.

The tentatively identified cyclosiloxanes (i.e., Cmpd \# 17 and 24 in Table 4-7) may also have been sent to tank TY-101 with other wastes. Small quantities of organo-silicon compounds may have been introduced to the waste tank through their use as defoaming agents, but they may also be present in the headspace due to their use in liquid traps at the tank's breather riser. Several of these have also been observed in TST blanks, however, and they may be present as artifacts of the gas chromatography process.

The absence of tributyl phosphate in the tank TY-101 samples does not necessarily indicate it is not present in the headspace or the waste. The identification of the tributyl phosphate diluents and their degradation products is reason to expect tributyl phosphate may be present in the tank waste. 1-Butanol, which was positively identified in tank TY-101 TST samples, is known to be a product of the hydrolysis of tributyl phosphate. Furthermore, informal tests by ORNL. indicate that tributyl phosphate is adsorbed by the glass fiber filters used during sampling to protect the samples from radiolytic particulate contamination. Based on these considerations, the lack of tributyl phosphate in the tank TY-101 headspace samples should not be taken as proof it is not present in the headspace or the waste.

A relatively large number of halogenated organic compounds were detected in samples from tank TY-101, including 1,1,1-trichloroethane, and tetrachloroethene. These compounds may have been used as cleaning solvents and may have been sent to the waste tanks when they became radiologically contaminated. Cmpd \# 40 in Table 4-7 (2,3,3',5'-tetrachloro-1, $1^{\prime}$-biphenyl) is a polychlorinated biphenyl (PCB).

The second category includes all organic compounds that have been generated via radiolytic and chemical reactions of the waste. The majority of compounds listed in Tables 4-1 through 4-9 fall into this category, 


\section{WHC-SD-WM-ER-461 REV. 1}

including the alcohols, aldehydes, alkenes, ketones, nitriles, and volatile alkanes, all of which have been associated with the degradation of the NPHs.

The total organic vapor concentration of tank TY-101 was estimated by Jenkins et al, to be about $1.0 \mathrm{mg} / \mathrm{m}^{3}$ from the analysis of 3 TST samples by GCMS. A similar summation of organic compounds measured in SUMMA ${ }^{T M}$ samples from tank TY-101 provides an estimated total organic vapor concentration of 1.65 $\mathrm{mg} / \mathrm{m}^{3}$. This is a relatively low concentration of organic vapors compared to most other passively ventilated tanks that have been sampled.

In summary, the organic vapors in tank TY-101 clearly indicate the presence of the semivolatile NPHs and their degradation products in the tank waste, though the NPHs are at trace levels. Tributyl phosphate was not detected in any of the headspace samples, but there is strong evidence that it is also present in the waste. 


\subsection{SUMMARY}

The tank TY-101 headspace was sampled in August 1994 and April 1995 for gases and vapors to address flammability and industrial hygiene concerns. Results unique to the August 1994 event and essentially all results from the April 1995 event have been reported. It was determined that no headspace constituents exceeded the flammability or industrial hygiene notification limits specified in the current Vapor Sampling and Analysis Plan (Homi 1995). 
THIS PAGE INTENTIONALIY

IEIT BLANK 


\subsection{REFERENCES}

29 CFR 1910.120, 1993, "Hazardous Waste Operations and Emergency Response", Code of Federal Regulations.

Burnum, S. T., 1995, Qualification of Reported WHC Vapor Program Data, (letter 95-CHD-065 to president, Westinghouse Hanford Company, August 18), Department of Energy, Richland Operations Office, Richland, Washington.

Cashdollar, K. L..,M. Hertzberg, I. A. Zlochower, C. E. Lucci, G. M. Green, and R. A. Thomas, 1992, Laboratory Flammability Studies of Mixtures of Hydrogen, Nitrous Oxide, and Air, WHC-SD-WMES-219 Rev. 0, Westinghouse Hanford Company, Richland, Washington.

Dougherty, L. F., 1995, Single Shell Tank Interim Operational Safety Requirements, WHC-SD-WM-OSR005 Rev. 0, Westinghouse Hanford company, Richland, Washington.

EPA 1988, Compendium of Methods for the Determination of Toxic Organic Compounds in Ambient Air, PB90-127374, U.S. Environmental Protection Agency, Washington, D.C.

EPA 1992, Test Methods for Evaluating Solid Waste, SW-846 Rev. 1, U.S. Environmental Protection Agency, Washington, D.C.

Fariey, W. G., 1991, Safety Assessment for Gas Sampling All Ferrocyanide Tanks, WHC-SD-WM-SAD-009 Rev. 2, Westinghouse Hanford Company, Richland, Washington.

Hendrickson, R. W., 1995, Tank Vapor Characterization Oak Ridge National Laboratories Quality Assurance Assessment, TWRSQA-95-0012, Westinghouse Hanford Company, Richland, Washington.

Homi, C. S., 1995, Tank 241-TY-101 Tank Characterization Plan, WHC-SD-WM-TP-299 Rev. OA, Westinghouse Hanford Company, Richland, Washington.

Huckaby, J. L., 1994a, Vapor Sampling System (VSS) and In Situ Sampling (ISS) Method Comparison, WHC-SD-WM-RPT-101 Rev. 0, Westinghouse Hanford Company, Richland, Washington.

Huckaby, J. L., 1994b, Tank 241-C-103 Headspace Flammability, WHC-EP-0734 Rev. 1, Westinghouse Hanford Company, Richland, Washington.

Huckaby, J. L., H. Babad, and D. R. Bratzel, 1995, Headspace Gas and Vapor Characterization Summary for the 43 Vapor Program Suspect Tanks, WHC-SD-WM-ER-514 Rev. 0, Westinghouse Hanford Company, Richland, Washington.

Huckaby, J. L., and M. S. Story, 1994, Vapor Characterization of Tank 241-C-103, WHC-EP-0780 Rev. 0, Westinghouse Hanford Company, Richland, Washington.

Jenkins, R. A., 1995a, Untitled, (Letter 090195A to D. Bratzel, September 1), Oak Ridge National Laboratory, Oak Ridge, Tennessee.

Jenkins, R. A., 1995b, Untitled, (Letter 091495A to D. Bratzel, September 14), Oak Ridge National Laboratory, Oak Ridge, Tennessee. 


\section{WHC-SD-WM-ER-461 REV. 1}

Jenkins, R. A, A. B. Dindal, C. Y. Ma, M. A. Palausky, J. T. Skeen, and C. K. Bayne, 1995a, Analysis of Tank 241-TY-101 Headspace Components, ORNL-CASD-FR-241TY101.95 Rev. 0, Oak Ridge National Laboratory, Oak Ridge, Tennessee.

Jenkins, R. A, A. B. Dindal, C. Y. Ma, M. A. Palausky, J. T. Skeen, and C. K. Bayne, 1995b, Analysis of Tank 241-TY-104 Headspace Components, ORNL-CASD-FR-241TY104.95 Rev. 1, Oak Ridge National Laboratory, Oak Ridge, Tennessee.

Keller, K.K., 1994, Quality Assurance Project Plan for Tank Vapor Characterization, WHC-SD-WM-QAPP013 Rev.2, Westinghouse Hanford Company, Richland, Washington.

Klinger, G. S., T. W. Clauss, M. W. Ligotke, K. H. Pool, B. D. MoVeety, K. B. Olsen, O. P. Bredt, J. S. Fruchter, and S. C. Goheen, 1995, Vapor Space Characterization of Waste Tank 241-TY-101: Results from Samples Collected on 4/6/95, PNL-10706 UC-606, Pacific Northwest Laboratory, Richland, Washington.

Ligotke, M. W. 1995, PNL Vapor Project Analytical Holding Times, (Letter to D.R. Bratzel, September 23, 1995), Pacific Northwest Laboratory, Richland, Washington.

Lucke, R. B., M. W. Ligotke, K. H. Pool, T. W. Clauss, A. K. Sharma, B. D. MoVeety, M. MoCulloch, J. S. Fruchter, and S. C. Goheen, 1995, Vapor Space Characterization of Waste Tank 241-C-108: Results from Samples Collected Through the Vapor Sampling System on 8/5/94, PNL-10351 UC606 , Pacific Northwest Laboratory, Richland, Washington.

Mahlum, D. D., J. Y. Young, and R. E. Weller, 1994, Toxicologic Evaluation of Analytes from Tank 231-C103, PNL-10189, Pacific Northwest Laboratory, Richland, Washington.

Mahon, R., 1995, FY 1994 In-Situ Sampling System Summary Report, (Letter OM624-95-055 to D. Bratzel), Westinghouse Hanford Company, Richland, Washington.

McVeety, B. D., T. W. Clauss, M. W. Ligotke, K. H. Pool, R. B. Lucke, G. S. Klinger, J. S. Young, M. McCulloch, J. S. Fruchter, and S. C. Goheen, 1995, Vapor Space Characterization of Waste Tank 241-BY-108: Results from Samples Collected on 10/27/94, PNL-10495 UC-606, Pacific Northwest Laboratory, Richland, Washington.

Meacham, J. E., H. Babad, R. J. Cash, G. T. Dukelow, S. J. Eberlein, D. W. Hamilton, G. D. Johnson, J. W. Osborne, M. A. Payne, D. J. Sherwood, D. A. Turner, and J. L. Huckaby, 1995, Approach for Tank Safety Characterization of Hanford Site Waste, WHC-EP-0843 Rev. 0, UC-2070, Westinghouse Hanford Company, Richland, Washington.

NFPA 1992, Standard on Explosion Prevention Systems, NFPA 69, National Fire Protection Association, Quincy, Massachusetts.

Osborne, J. W., and J. L. Huckaby, 1994, Program Plan for the Resolution of Tank Vapor Issues, WHC-EP0562 Rev. 1, Westinghouse Hanford Company, Richland, Washington.

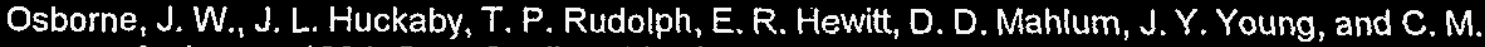
Anderson, 1994, Data Quality Objectives for Generic In-Tank Health and Safety Issue Resolution, WHC-SD-WM-DQO-002, Westinghouse Hanford Company, Richland, Washington. 


\section{WHC-SD-WM-ER-461 REV. 1}

Pingel, L. A., 1994, Data Report from the In-Situ Vapor Sampling of Wasste Tank TY-101, (internal memorandum 8H130-SAS94-108 to J. L. Huckaby, August 19), Westinghouse Hanford Company, Richland, Washington.

Pool, K. H., T. W. Clauss, M. W. Ligotke, R. B. Lucke, B. D. MoVeety, J. S. Young, M. McCulloch, J. S. Fruchter, and S. C. Goheen, 1995, Vapor Space Characterization of Waste Tank 241-TY-101 (n Situ): Results from Samples Collected on 8/5/94, PNL-10473 UC-606, Pacific Northwest Laboratory, Richland, Washington.

WHC 1995a, Operating Specifications for Watchlist Tanks, OSD-T-151-00030, Rev. B-9, Westinghouse Hanford Company, Richland, Washington.

WHC 1995b, Vapor and Gas Sampling of Single-Shell Tank 241-TY-101 Using the Vapor Sampling System, WHC-SD-WM-RPT-146 Rev. 0, Westinghouse Hanford Company, Richland, Washington.

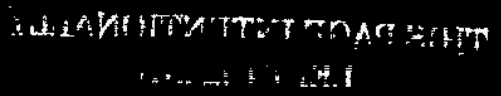


THIS PAGE INTENTIONAELY

LEET BLANK 


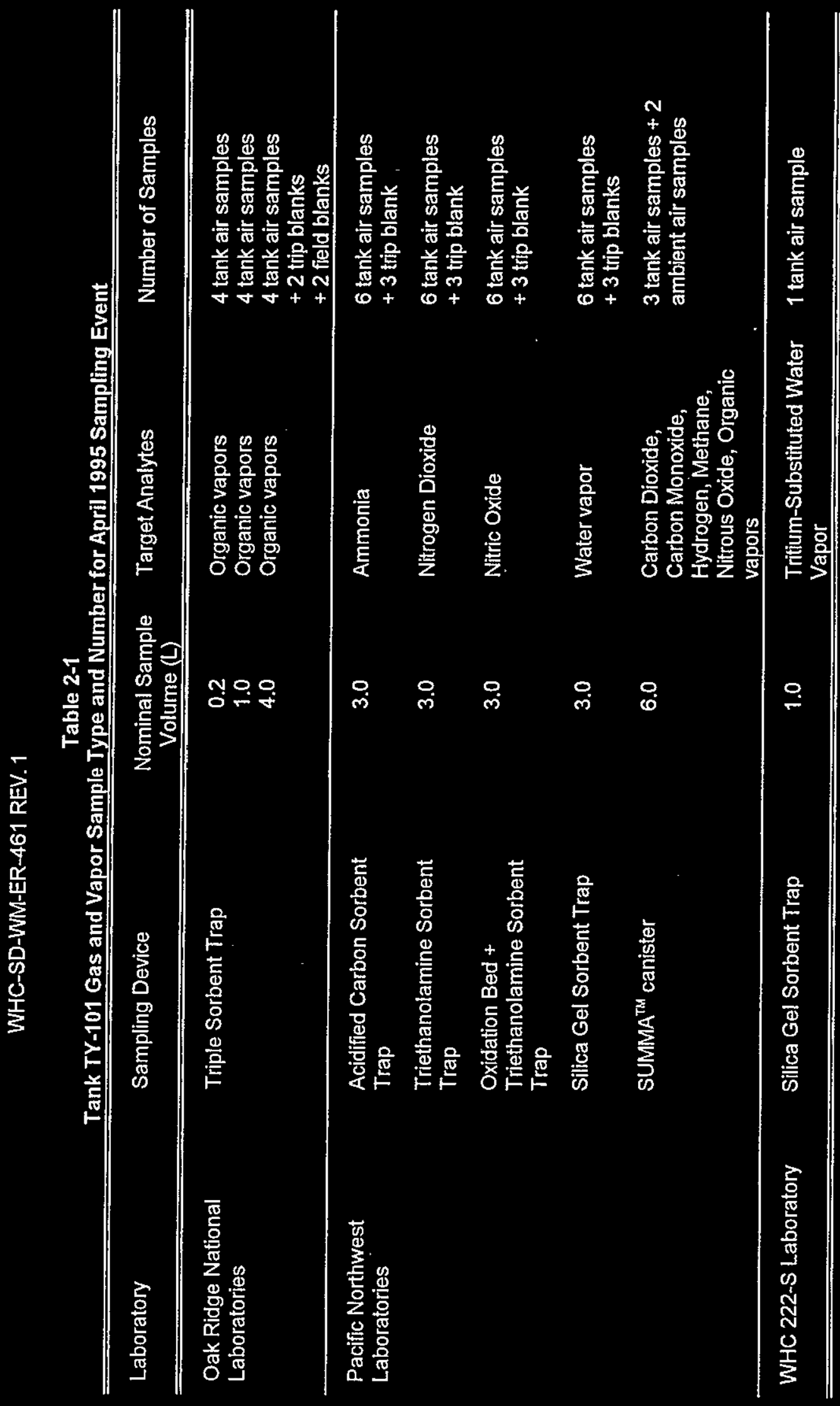




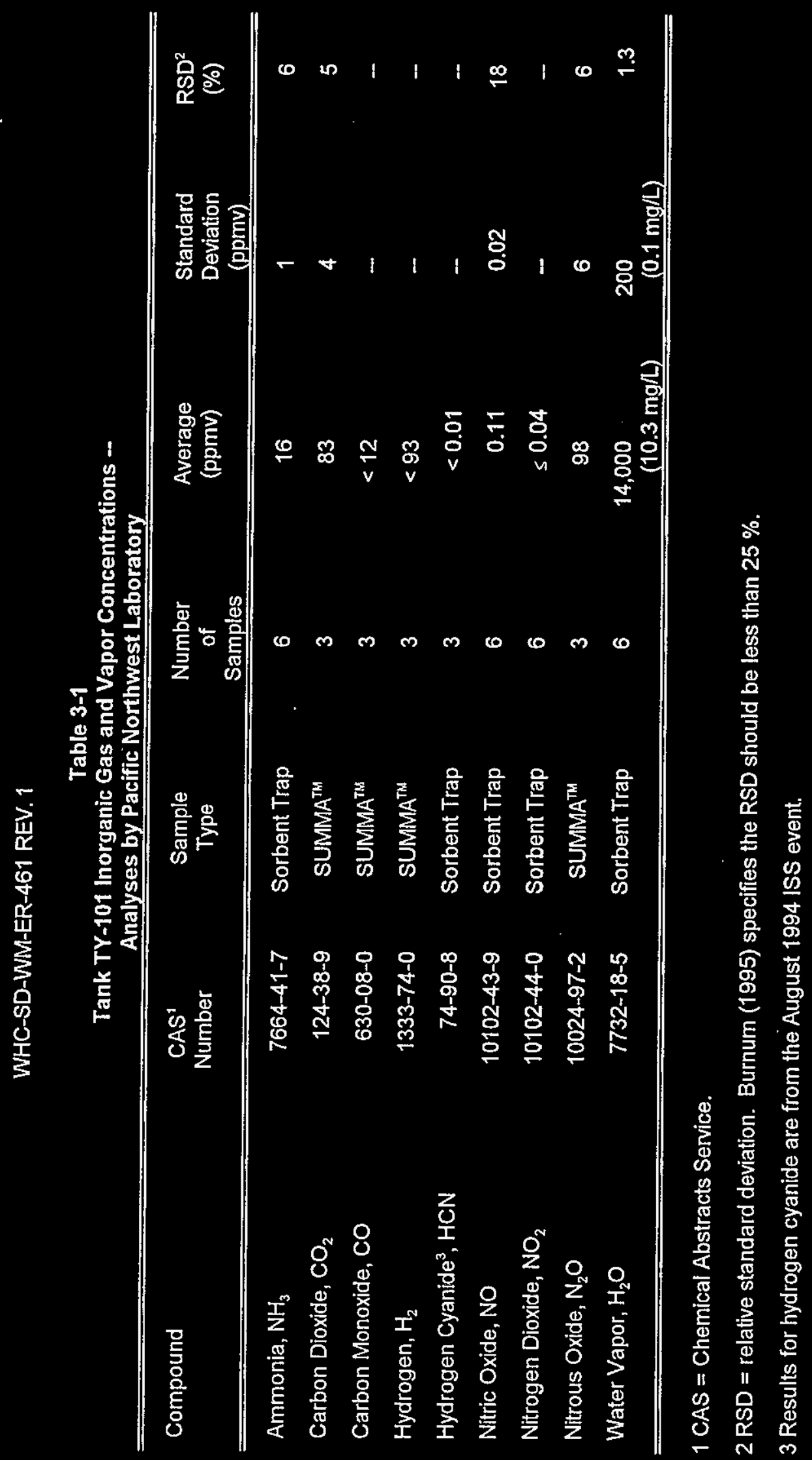


WHC-SD-WM-ER-461 REV. 1

Table 4-1

Tank TY-101 Positively Identified Organic Compounds in SUMMA ${ }^{\text {TM }}$ Samples Analyses by Pacific Northwest Laboratory

\begin{tabular}{clcccc}
\hline \hline $\begin{array}{c}\text { Cmpd } \\
\#\end{array}$ & Compound & $\begin{array}{c}\mathrm{CAS}^{1} \\
\text { Number }\end{array}$ & $\begin{array}{c}\text { Average } \\
\text { (ppmv) }\end{array}$ & $\begin{array}{c}\text { Standard } \\
\text { Deviation } \\
\text { (ppmv) }\end{array}$ & $\begin{array}{c}\mathrm{RSD}^{3} \\
(\%)\end{array}$ \\
\hline \hline 1 & Ethanenitrile (acetonitrile) & $75-05-8$ & 0.079 & 0.008 & 10 \\
2 & Propanone (acetone) & $67-64-1$ & 0.14 & 0.02 & 15 \\
3 & Trichlorofluoromethane & $75-69-4$ & 0.040 & 0.008 & 21 \\
4 & Propanenitrile & $107-12-0$ & 0.006 & 0.0007 & 12 \\
5 & Tetrachloromethane (carbon & $56-23-5$ & 0.006 & 0.0001 & 2 \\
6 & tetrachloride) & 2-Butanone & & & - \\
7 & Methane & $78-93-3$ & 0.008 & - & - \\
\hline \hline
\end{tabular}

$1 \mathrm{CAS}=$ Chemical Abstract Service.

2 Average of 3 samples.

$3 \mathrm{RSD}=$ relative standard deviation. Burnum (1995) specifies the RSD should be less than $25 \%$.

4 Detected in only 1 sample. 
WHC-SD-WM-ER-461 REV. 1

Table 4-2

Tank TY-101 Quantitatively Measured Organic Compounds in TST Samples Analyses by Oak Ridge National Laboratory'

\begin{tabular}{clcccc}
\hline \hline $\begin{array}{c}\text { Cmpd } \\
\#\end{array}$ & Compound & $\begin{array}{c}\mathrm{CAS}^{2} \\
\text { Number }\end{array}$ & $\begin{array}{c}\text { Average } \\
(\mathrm{ppmv})\end{array}$ & $\begin{array}{c}\text { Standard } \\
\text { Deviation } \\
\text { (ppmv) }\end{array}$ & $\begin{array}{c}\mathrm{RSD}^{4} \\
(\%)\end{array}$ \\
\hline \hline 1 & Ethanenitrile (acetonitrile) & $75-05-8$ & 0.029 & 0.005 & 16 \\
2 & n-Dodecane & $112-40-3$ & 0.0041 & 0.0002 & 6 \\
\hline \hline
\end{tabular}

1 Results in this table are quantitative (as defined in Section 4.1).

$2 \mathrm{CAS}=$ Chemical Abstract Service.

3 Average of 4 TST samples: 3 were $4-L$ and 1 was $1-L$.

4 RSD = relative standard deviation. Burnum (1995) specifies the RSD should be less than $25 \%$. 
WHC-SD-WM-ER-461 REV. 1

Table 4-3

Tank TY-101 Positively Identified Organic Compounds in TST Samples Analyses by Oak Ridge National Laboratory ${ }^{1}$

\begin{tabular}{|c|c|c|c|c|c|}
\hline$\underset{\#}{\text { Cmpd }}$ & Compound & $\begin{array}{l}\text { CAS }^{2} \\
\text { Number }\end{array}$ & $\begin{array}{l}\text { Average }^{3} \\
(\mathrm{ppmv})\end{array}$ & $\begin{array}{c}\text { Standard } \\
\text { Deviation } \\
\text { (ppmv) }\end{array}$ & $\begin{array}{l}\mathrm{RSD}^{4} \\
(\%)\end{array}$ \\
\hline 1 & Propanone (acetone) & $67-64-1$ & 0.084 & 0.011 & 13 \\
\hline 2 & $\begin{array}{l}\text { 1,1-Dichloroethene (vinylidene } \\
\text { chloride) }\end{array}$ & $75-35-4$ & 0.0024 & 0.0020 & 85 \\
\hline 3 & Propanenitrile & $107-12-0$ & 0.0038 & 0.0003 & 8 \\
\hline 4 & n-Hexane & $110-54-3$ & 0.00015 & 0.00008 & 57 \\
\hline 5 & Benzene & $71-43-2$ & 0.00022 & 0.00018 & 81 \\
\hline 6 & n-Butanenitrile & $109-74-0$ & 0.0012 & 0.0001 & 9 \\
\hline 7 & 2-Pentanone & $107-87-9$ & 0.00064 & 0.00047 & 73 \\
\hline 8 & Toluene & $108-88-3$ & 0.00065 & 0.00054 & 82 \\
\hline 9 & n-Pentanentrile & $110-59-8$ & 0.00036 & 0.00002 & 6 \\
\hline 10 & 2-Hexanone & $591-78-6$ & 0.00033 & 0.00030 & 91 \\
\hline 11 & n-Octane & $111-65-9$ & 0.000055 & 0.000038 & 69 \\
\hline 12 & $\mathrm{n}$-Hexanenitrile & $628-73-9$ & 0.00011 & 0.00008 & 67 \\
\hline 13 & 2-Heptanone & $110-43-0$ & 0.00022 & 0.00008 & 38 \\
\hline 14 & n-Nonane & $111-84-2$ & 0.00011 & 0.00008 & 74 \\
\hline 15 & n-Heptanenitrile & $629-08-3$ & 0.000088 & 0.000059 & 67 \\
\hline 16 & 2-Octanone & $111-13-7$ & 0.000085 & 0.000057 & 67 \\
\hline 17 & n-Decane & $124-18-5$ & 0.00015 & 0.00005 & 32 \\
\hline 18 & n-Undecane & $1120-21-4$ & 0.00036 & 0.00007 & 20 \\
\hline 19 & n-Tridecane & $629-50-5$ & 0.015 & 0.002 & 15 \\
\hline
\end{tabular}

1 Results in this table are not quantitative (as defined in Section 4.1) because measured values in at least 1 of the samples are outside instrument calibration limits.

$2 \mathrm{CAS}=$ Chemical Abstract Service.

3 Average of 4 TST samples: 3 were $4-L$ and 1 was 1-L.

$4 \mathrm{RSD}=$ relative standard deviation. Burnum (1995) specifies the RSD should be less than $25 \%$. 


\section{WHC-SD-WM-ER-461 REV. 1}

Table 4-4

Tank TY-101 Positively Identified Compounds in TST Samples for which Practical Holding Times were Exceeded Analyses by Oak Ridge National Laboratory ${ }^{1}$

\begin{tabular}{clrrrr}
\hline $\begin{array}{c}\text { Cmpd } \\
\#\end{array}$ & Compound & $\begin{array}{c}\text { CAS }^{2} \\
\text { Number }\end{array}$ & $\begin{array}{c}\text { Average } \\
\text { (ppmv) }\end{array}$ & $\begin{array}{c}\text { Standard } \\
\text { Deviation } \\
\text { (ppmv) }\end{array}$ & $\begin{array}{c}\mathrm{R}^{\mathrm{RSD}}{ }^{4} \\
(\%)\end{array}$ \\
\hline \hline & Butanal $^{5}$ & $123-72-8$ & 0.0071 & 0.0010 & 15 \\
2 & 1-Butanol $^{5}$ & $71-36-3$ & 0.0027 & 0.0005 & 19 \\
\hline \hline
\end{tabular}

1 Practical holding times are defined and discussed in Section 4.1.

$2 \mathrm{CAS}=$ Chemical Abstract Service.

3 Average of 4 TST samples: 3 were $4-L$ and 1 was $1-L$.

4 RSD = relative standard deviation. Burnum (1995) specifies the RSD should be less than $25 \%$.

5 The concentration of this analyte was not quantitatively measured (as defined in Section 4.1), because the measured concentration was outside of the instrumental calibration limits. 
Table 4-5

Tank TY-101 Comparison of Organic Compounds in TST and SUMMA ${ }^{\text {TM }}$ Samples Analyses by Pacific Northwest Laboratory and Oak Ridge National Laboratory

\begin{tabular}{lcccc}
\hline \hline Compound & $\begin{array}{c}\text { CAS }^{1} \\
\text { Number }\end{array}$ & $\begin{array}{c}\mathrm{TST}^{\text {Average }}{ }^{2} \\
\text { (ppmv) }\end{array}$ & $\begin{array}{c}\text { SUMMA }_{\text {Average }^{3}} \\
\text { (ppmv) }\end{array}$ & $\begin{array}{c}\text { PRD }^{4} \\
(\%)\end{array}$ \\
\hline \hline 1,1-Dichloroethene (vinylidene chloride) & $75-35-4$ & 0.0024 & $<0.005$ & - \\
Dichloromethane (methylene chloride) & $75-09-2$ & $<0.0013$ & $<0.005$ & - \\
Propanone (acetone) & $67-64-1$ & 0.084 & 0.14 & 50 \\
Ethanenitrile (acetonitrile) & $75-05-8$ & 0.029 & 0.079 & 92 \\
Propanenitrile & $107-12-0$ & 0.0038 & 0.006 & 45 \\
n-Butanenitrile & $109-74-0$ & 0.0012 & $<0.005$ & - \\
Benzene & $71-43-2$ & 0.00022 & $<0.005$ & - \\
Toluene & $108-88-3$ & 0.00065 & $<0.005$ & - \\
n-Hexane & $110-54-3$ & 0.00015 & $<0.005$ & - \\
n-Heptane & $142-82-5$ & $<0.00011$ & $<0.005$ & - \\
n-Decane & $124-18-5$ & 0.00015 & $<0.005$ & - \\
\hline \hline
\end{tabular}

$1 \mathrm{CAS}=$ Chemical Abstract Service.

2 Average of 4 TST samples: 3 were $4-L$ and 1 was $1-L$.

3 Average of 3 sample analyses by PNL.

$4 \mathrm{PRD}=$ percent relative difference. Keller (1994) requires the PRD to be less than $20 \%$. 
Table 4-6

Tank TY-101 Tentatively Identified Organic Compounds in SUMMA ${ }^{\text {TM }}$ Samples Analyses by Pacific Northwest Laboratory

\begin{tabular}{ccccc}
\hline Cmpd \# Compound & $\begin{array}{c}\mathrm{CAS}^{1} \\
\text { Number }\end{array}$ & $\begin{array}{c}\text { Average } \\
\left(\mathrm{mg} / \mathrm{m}^{3}\right)\end{array}$ & $\begin{array}{c}\text { Standard } \\
\text { Deviation } \\
\left(\mathrm{mg} / \mathrm{m}^{3}\right)\end{array}$ \\
\hline \hline 1 & Methanol (methyl alcohol) & $67-56-1$ & 0.79 & 0.14 \\
\hline \hline
\end{tabular}

$1 \mathrm{CAS}=$ Chemical Abstract Service. 
Table 4-7

Tank TY-101 Tentatively ldentified Organic Compounds in TST Samples in Order of Chromatographic Elution Analyses by Oak Ridge National Laboratory

\begin{tabular}{|c|c|c|c|c|}
\hline$\underset{\#}{\text { Cmpd }}$ & Compounds & $\begin{array}{l}\text { CAS }^{1} \\
\text { Number }\end{array}$ & $\begin{array}{l}\text { Average } \\
\left(\mathrm{mg} / \mathrm{m}^{3}\right)\end{array}$ & $\begin{array}{l}\text { Standard } \\
\text { Deviation } \\
\left(\mathrm{mg} / \mathrm{m}^{3}\right)\end{array}$ \\
\hline 1 & Methanol & $67-56-1$ & 0.050 & 0.036 \\
\hline 2 & Dichlorofluoromethane & $75-43-4$ & 0.00077 & 0.00090 \\
\hline 3 & Ethanol & $64-17-5$ & 0.0020 & 0.0013 \\
\hline 4 & Trichlorofluoromethane & $75-69-4$ & 0.042 & 0.009 \\
\hline 5 & Silane, chlorotrimethyl & $75-77-4$ & 0.0064 & 0.0091 \\
\hline 6 & 2-Propanol (isopropyl alcohol) & $67-63-0$ & 0.0090 & 0.0023 \\
\hline 7 & Ethane, 1,1,2-trichloro-1, 2-2-trifluoro- & $76-13-1$ & 0.00043 & 0.00086 \\
\hline 8 & Hydrazine, methyl- & $60-34-4$ & 0.0021 & 0.0016 \\
\hline 9 & 2-Butanone & $78-93-3$ & 0.00047 & 0.00094 \\
\hline 10 & Trichloromethane (chloroform) & $67-66-3$ & 0.00096 & 0.00111 \\
\hline 11 & Ethane, 1,1,1-trichloro- & $71-55-6$ & 0.00042 & 0.00084 \\
\hline 12 & Nitric acid, propyl ester & $627-13-4$ & 0.00033 & 0.00066 \\
\hline 13 & Propylene Glycol & $57-55-6$ & 0.072 & 0.070 \\
\hline 14 & Furan, 2,3-dihydro- & $1191-99-7$ & 0.00039 & 0.00078 \\
\hline 15 & Hexanal & $66-25-1$ & 0.0017 & 0.0012 \\
\hline 16 & Tetrachloroethylene & $127-18-4$ & 0.0080 & 0.0002 \\
\hline 17 & Cyclotrisiloxane, hexamethyl & $541-05-9$ & 0.036 & 0.051 \\
\hline 18 & Heptanal & $111-71-7$ & 0.0036 & 0.0014 \\
\hline 19 & Pentanol, 5-amino- & $2508-29-4$ & 0.0016 & 0.0011 \\
\hline 20 & 2(3H)-Furanone, dihydro-5-methyl- & $108-29-2$ & 0.00036 & 0.00071 \\
\hline 21 & Cyclotetrasiloxane, octamethyl & $556-67-2$ & 0.017 & 0.021 \\
\hline 22 & Octanal & $124-13-0$ & 0.0021 & 0.0015 \\
\hline 23 & 1-Hexanol, 2-ethyl- & $104-76-7$ & 0.0015 & 0.0010 \\
\hline 24 & 2(3H)-Furanone, 5-ethyldihydro- & $695-06-7$ & 0.0014 & 0.0009 \\
\hline 25 & Nonanal & $124-19-6$ & 0.0025 & 0.0017 \\
\hline 26 & $\begin{array}{l}\text { Benzoic acid, 2-[(trimethylsilyl) } \\
\text { oxy]-trimethylsilyl ester }\end{array}$ & $3789-85-3$ & 0.0062 & 0.0090 \\
\hline
\end{tabular}


WHC-SD-WM-ER-461 REV. 1

\begin{tabular}{|c|c|c|c|c|}
\hline$\underset{\#}{\text { Cmpd }}$ & Compounds & $\begin{array}{l}\text { CAS }^{1} \\
\text { Number }\end{array}$ & $\begin{array}{l}\text { Average }^{2} \\
\left(\mathrm{mg} / \mathrm{m}^{3}\right)\end{array}$ & $\begin{array}{l}\text { Standard } \\
\text { Deviation } \\
\left(\mathrm{mg} / \mathrm{m}^{3}\right)\end{array}$ \\
\hline 27 & 3-Dodecene, (E)- & $7206-14-6$ & 0.00033 & 0.00067 \\
\hline 28 & Decanal & $112-31-2$ & 0.00069 & 0.00080 \\
\hline 29 & Methenamine & $100-97-0$ & 0.024 & 0.035 \\
\hline 30 & Cyclohexane, 2-butyl-1,1,3-trimethyl- & $54676-39-0$ & 0.0004 & 0.0007 \\
\hline 31 & $\begin{array}{l}\text { 2-Furancarboxylic acid, hexyl ester and } \\
\text { others }\end{array}$ & & 0.0012 & 0.0008 \\
\hline 32 & 2,2'-Bioxepane & $74793-02-5$ & 0.0015 & 0.0010 \\
\hline 33 & $\mathrm{n}$-Tetradecane & $629-59-4$ & 0.052 & 0.004 \\
\hline 34 & 6-Tridecanone & $22026-12-6$ & 0.0036 & 0.0032 \\
\hline 35 & n-Pentadecane & $629-62-9$ & 0.0039 & 0.0026 \\
\hline 36 & n-Hexadecane & $544-76-3$ & 0.00067 & 0.00077 \\
\hline 37 & Isopropyl Myristate & $110-27-0$ & 0.0066 & 0.0133 \\
\hline 38 & 1-Pentadecanol & $629-76-5$ & 0.0053 & 0.0106 \\
\hline 39 & Benzenesulfonamide, $\mathrm{N}$-butyl & $3622-84-2$ & 0.0079 & 0.0068 \\
\hline 40 & 1,1'-Biphenyl, 2,3,3',5'-tetrachloro- & $41464-49-7$ & 0.0037 & 0.0025 \\
\hline 41 & Isopropyl Palmitate & $142-91-6$ & 0.13 & 0.26 \\
\hline 42 & Hexadecanoic acid & $57-10-3$ & 0.0034 & 0.0068 \\
\hline \multicolumn{2}{|c|}{ Sum of tentatively identified compounds: } & & $0.51 \mathrm{mg} / \mathrm{ms}^{3}$ & \\
\hline
\end{tabular}

$1 \mathrm{CAS}=$ Chemical Abstract Service .

2 Average of 4 TST samples: 3 were $4-L$ and 1 was 1-L, values listed are estimates. 
WHC-SD-WM-ER-461 REV. 1

Table 4m8

Tank TY-101 Tentatively Identified Organic Compounds in TST Samples

Sorted Alphanumerically -

Analyses by Oak Ridge National Laboratory

\begin{tabular}{|c|c|c|c|c|}
\hline $\begin{array}{c}\text { Cmpd } \\
\#\end{array}$ & Compounds & $\begin{array}{l}\text { CAS }^{1} \\
\text { Number }\end{array}$ & $\begin{array}{l}\text { Average } \\
\left(\mathrm{mg} / \mathrm{m}^{3}\right)\end{array}$ & $\begin{array}{l}\text { Standard } \\
\text { Deviation } \\
\left(\mathrm{mg} / \mathrm{m}^{3}\right)\end{array}$ \\
\hline 38 & 1-Pentadecanol & $629-76-5$ & 0.0053 & 0.0106 \\
\hline 23 & 1-Hexanol, 2-ethyl- & $104-76-7$ & 0.0015 & 0.0010 \\
\hline 31 & $\begin{array}{l}\text { 2-Furancarboxylic acid, hexyl ester and } \\
\text { others }\end{array}$ & & 0.0012 & 0.0008 \\
\hline 9 & 2-Butanone & $78-93-3$ & 0.00047 & 0.00094 \\
\hline 6 & 2-Propanol (isopropyl alcohol) & $67-63-0$ & 0.0090 & 0.0023 \\
\hline 27 & 3-Dodecene, $(E)$ - & $7206-14-6$ & 0.00033 & 0.00067 \\
\hline 34 & 6-Tridecanone & $22026-12-6$ & 0.0036 & 0.0032 \\
\hline 40 & 1,1'-Biphenyl, 2,3,3',5'-tetrachloro- & $41464-49-7$ & 0.0037 & 0.0025 \\
\hline 32 & 2,2'-Bioxepane & 74793-02-5 & 0.0015 & 0.0010 \\
\hline 20 & 2(3H)-Furanone, dihydro-5-methyl- & $108-29-2$ & 0.00036 & 0.00071 \\
\hline 24 & 2(3H)-Furanone, 5-ethyldihydro- & $695-06-7$ & 0.0014 & 0.0009 \\
\hline 39 & Benzenesulfonamide, $\mathrm{N}$-butyl & $3622-84-2$ & 0.0079 & 0.0068 \\
\hline 26 & $\begin{array}{l}\text { Benzoic acid, } 2 \text {-[(trimethyisilyl) } \\
\text { oxy]-trimethylsilyl ester }\end{array}$ & $3789-85-3$ & 0.0062 & 0.0090 \\
\hline 30 & Cyclohexane, 2-butyl-1,1,3-trimethyl- & $54676-39-0$ & 0.0004 & 0.0007 \\
\hline 21 & Cyclotetrasiloxane, octamethyl & $556-67-2$ & 0.017 & 0.021 \\
\hline 17 & Cyclotrisiloxane, hexamethyl & $541-05-9$ & 0.036 & 0.051 \\
\hline 28 & Decanal & $112-31-2$ & 0.00069 & 0.00080 \\
\hline 2 & Dichlorofluoromethane & $75-43-4$ & 0.00077 & 0.00090 \\
\hline 7 & Ethane, 1,1,2-trichloro-1,2-2-trifluoro- & $76-13-1$ & 0.00043 & 0.00086 \\
\hline 11 & Ethane, 1,1,1-trichloro- & $71-55-6$ & 0.00042 & 0.00084 \\
\hline 3 & Ethanol & $64-17-5$ & 0.0020 & 0.0013 \\
\hline 14 & Furan, 2,3-dihydro- & $1191-99-7$ & 0.00039 & 0.00078 \\
\hline 18 & Heptanal & $111-71-7$ & 0.0036 & 0.0014 \\
\hline 42 & Hexadecanoic acid & $57-10-3$ & 0.0034 & 0.0068 \\
\hline 15 & Hexanal & $66-25-1$ & 0.0017 & 0.0012 \\
\hline
\end{tabular}


WHC-SD-WM-ER-461 REV. 1

\begin{tabular}{|c|c|c|c|c|}
\hline$\underset{\#}{\text { Cmpd }}$ & Compounds & $\begin{array}{c}\text { CAS }^{1} \\
\text { Number }\end{array}$ & $\begin{array}{c}\text { Average }^{2} \\
\left(\mathrm{mg} / \mathrm{m}^{3}\right)\end{array}$ & $\begin{array}{c}\text { Standard } \\
\text { Deviation } \\
\left(\mathrm{mg} / \mathrm{m}^{3}\right) \\
\end{array}$ \\
\hline 8 & Hydrazine, methyl- & $60-34-4$ & 0.0021 & 0.0016 \\
\hline 41 & Isopropyl Palmitate & $142-91-6$ & 0.13 & 0.26 \\
\hline 37 & Isopropyl Myristate & $110-27-0$ & 0.0066 & 0.0133 \\
\hline 1 & Methanol & $67-56-1$ & 0.050 & 0.036 \\
\hline 29 & Methenamine & $100-97-0$ & 0.024 & 0.035 \\
\hline 36 & nuHexadecane & $544-76 \sim 3$ & 0.00067 & 0.00077 \\
\hline 35 & n-Pentadecane & $629-62-9$ & 0.0039 & 0.0026 \\
\hline 33 & n-Tetradecane & $629-59-4$ & 0.052 & 0.004 \\
\hline 12 & Nitric acid, propyl ester & $627-13-4$ & 0.00033 & 0.00066 \\
\hline 25 & Nonanal & $124-19-6$ & 0.0025 & 0.0017 \\
\hline 22 & Octanal & $124-13-0$ & 0.0021 & 0.0015 \\
\hline 19 & Pentanol, 5-amino- & $2508-29-4$ & 0.0016 & 0.0011 \\
\hline 13 & Propylene Glycol & $57-55-6$ & 0.072 & 0.070 \\
\hline 5 & Silane, chlorotrimethyl & $75-77-4$ & 0.0064 & 0.0091 \\
\hline 16 & Tetrachloroethylene & $127-18-4$ & 0.0080 & 0.0002 \\
\hline 4 & Trichlorofluoromethane & $75-69-4$ & 0.042 & 0.009 \\
\hline 10 & Trichloromethane (chloroform) & $67-66-3$ & 0.00096 & 0.00111 \\
\hline
\end{tabular}

$1 \mathrm{CAS}=$ Chemical Abstract Service

2 Average of 4 TST samples: 3 were $4-L$ and 1 was $1-L$, values listed are estimates. 
Table 4-9

Tank TY-101 Tentatively Identified Organic Compounds in TST Samples Sorted by Estimated Concentration --

Analyses by Oak Ridge National Laboratory

\begin{tabular}{|c|c|c|c|c|}
\hline$\underset{\#}{\text { Cmpd }}$ & Compounds & $\begin{array}{c}\text { CAS }^{1} \\
\text { Number }\end{array}$ & $\begin{array}{l}\text { Average }^{2} \\
\left(\mathrm{mg} / \mathrm{m}^{3}\right)\end{array}$ & $\begin{array}{l}\text { Standard } \\
\text { Deviation } \\
\left(\mathrm{mg} / \mathrm{m}^{3}\right)\end{array}$ \\
\hline 41 & Isopropyl Palmitate & $142-91-6$ & 0.13 & 0.26 \\
\hline 13 & Propylene Glycol & $57-55-6$ & 0.072 & 0.070 \\
\hline 33 & n-Tetradecane & $629-59-4$ & 0.052 & 0.004 \\
\hline 1 & Methanol & $67-56-1$ & 0.050 & 0.036 \\
\hline 4 & Trichlorofluoromethane & $75-69-4$ & 0.042 & 0.009 \\
\hline 17 & Cyclotrisiloxane, hexamethyl & $541-05-9$ & 0.036 & 0.051 \\
\hline 29 & Methenamine & $100-97-0$ & 0.024 & 0.035 \\
\hline 21 & Cyclotetrasiloxane, octamethyl & $556-67-2$ & 0.017 & 0.021 \\
\hline 6 & 2-Propanol (isopropyl alcohol) & $67-63-0$ & 0.0090 & 0.0023 \\
\hline 16 & Tetrachloroethylene & $127-18-4$ & 0.0080 & 0.0002 \\
\hline 39 & Benzenesulfonamide, $\mathrm{N}$-butyl & $3622-84-2$ & 0.0079 & 0.0068 \\
\hline 37 & Isopropyl Myristate & $110-27-0$ & 0.0066 & 0.0133 \\
\hline 5 & Silane, chlorotrimethyl & $75-77-4$ & 0.0064 & 0.0091 \\
\hline 26 & $\begin{array}{l}\text { Benzoic acid, 2-[(trimethyisilyl) } \\
\text { oxy]-trimethylsilyl ester }\end{array}$ & $3789-85-3$ & 0.0062 & 0.0090 \\
\hline 38 & 1-Pentadecanol & $629-76-5$ & 0.0053 & 0.0106 \\
\hline 35 & n-Pentadecane & $629-62-9$ & 0.0039 & 0.0026 \\
\hline 40 & 1,1'-Biphenyl, 2,3,3',5'-tetrachloro- & $41464-49-7$ & 0.0037 & 0.0025 \\
\hline 18 & Heptanal & $111-71-7$ & 0.0036 & 0.0014 \\
\hline 34 & 6-Tridecanone & $22026-12-6$ & 0.0036 & 0.0032 \\
\hline 42 & Hexadecanoic acid & $57-10-3$ & 0.0034 & 0.0068 \\
\hline 25 & Nonanal & $124-19-6$ & 0.0025 & 0.0017 \\
\hline 22 & Octanal & $124-13-0$ & 0.0021 & 0.0015 \\
\hline 8 & Hydrazine, methyl- & $60-34-4$ & 0.0021 & 0.0016 \\
\hline 3 & Ethanol & $64-17-5$ & 0.0020 & 0.0013 \\
\hline 15 & Hexanal & $66-25-1$ & 0.0017 & 0.0012 \\
\hline 19 & Pentanol, 5-amino- & $2508-29-4$ & 0.0016 & 0.0011 \\
\hline
\end{tabular}


WHC-SD-WM-ER-461 REV. 1

\begin{tabular}{|c|c|c|c|c|}
\hline$\underset{\#}{C \text { Cmpd }}$ & Compounds & $\begin{array}{l}\text { CAS }^{1} \\
\text { Number }\end{array}$ & $\begin{array}{l}\text { Average }^{2} \\
\left(\mathrm{mg} / \mathrm{m}^{3}\right)\end{array}$ & $\begin{array}{l}\text { Standard } \\
\text { Deviation } \\
\left(\mathrm{mg} / \mathrm{m}^{3}\right)\end{array}$ \\
\hline 23 & 1-Hexanol, 2-ethyl- & $104-76-7$ & 0.0015 & 0.0010 \\
\hline 32 & 2,2'-Bioxepane & 74793-02-5 & 0.0015 & 0.0010 \\
\hline 24 & $2(3 \mathrm{H})$-Furanone, 5-ethyldihydro- & $695-06-7$ & 0.0014 & 0.0009 \\
\hline 31 & $\begin{array}{l}\text { 2-Furancarboxylic acid, hexyl ester and } \\
\text { others }\end{array}$ & & 0.0012 & 0.0008 \\
\hline 10 & Trichloromethane (chloroform) & $67-66-3$ & 0.00096 & 0.00111 \\
\hline 2 & Dichlorofluoromethane & $75-43-4$ & 0.00077 & 0.00090 \\
\hline 36 & n-Hexadecane & $544-76-3$ & 0.00067 & 0.00077 \\
\hline 28 & Decanal & $112-31-2$ & 0.00069 & 0.00080 \\
\hline 11 & Ethane, 1,1,1-trichloro- & $71-55-6$ & 0.00042 & 0.00084 \\
\hline 9 & 2-Butanone & $78-93-3$ & 0.00047 & 0.00094 \\
\hline 30 & Cyclohexane, 2-butyl-1,1,3-trimethyl- & $54676-39-0$ & 0.0004 & 0.0007 \\
\hline 7 & Ethane, 1,1,2-trichioro-1, 2-2-trifluoro- & $76-13-1$ & 0.00043 & 0.00086 \\
\hline 12 & Nitric acid, propyl ester & $627-13-4$ & 0.00033 & 0.00066 \\
\hline 20 & 2(3H)-Furanone, dihydro-5-methyl- & $108-29-2$ & 0.00036 & 0.00071 \\
\hline 27 & 3-Dodecene, (E)- & $7206-14-6$ & 0.00033 & 0.00067 \\
\hline 14 & Furan, 2,3-dihydro- & 1191-99-7 & 0.00039 & 0.00078 \\
\hline
\end{tabular}

$1 \mathrm{CAS}=$ Chemical Abstract Service.

2 Average of 4 TST samples: 3 were $4-L$ and 1 was 1-L, values listed are estimates. 